\title{
Improving the quality of life in cities using community gardens: from benefits for members to benefits for all local residents
}

\author{
Lenka Dubová ${ }^{1 凶}-$ Jan Macháč ${ }^{1}$ \\ ${ }^{1}$ Institute for Economic and Environmental Policy, Faculty of Social and Economic Studies, Jan Evangelista Purkyně University \\ in Ústí nad Labem, Moskevská 54, 40096 Ústí nad Labem, Czechia \\ $\bowtie$ dubova@e-academia.eu
}

\begin{abstract}
Recent effects of globalization, urbanization and climate change have resulted in an increasing interest in the quality of life in cities and seeking pathways for its improvement. At the same time, there are changes in society and lifestyles that may challenge or facilitate these pathways. Community gardens (CGs) represent an effort to provide more sustainable urban economies, while reflecting on the public demand for cultivation of own crops. However, members of CGs may not perceive all the benefits that CGs provide for their surroundings. Using two case studied from Czechia (CG Kuchyňka and CG Vidimova in Prague) the aim of this paper is a comparison of the benefits perceived by community garden members and the evaluated net social benefits of community gardens in cities for all local residents. Through a questionnaire survey, the paper answers the research question of the benefits of community gardens perceived by community garden members. An economic assessment based on cost-benefit analysis was made to answer the question of the value of the net social benefits of community gardens in cities. Our comparison shows that the net social benefits are higher than perceived by their members. Net present benefits of EUR 31550 for CG Kuchyňka and EUR 1175 for CG Vidimova were quantified in a 50-year horizon. This economic analysis should contribute to greater support for community gardens by city governments and spatial planners.
\end{abstract}

\section{Highlights for public administration, management and planning:}

- Community gardens not only play a significant role for social interaction and relaxation, but can also contribute directly and indirectly to external benefits for the whole society.

- Community gardens provide benefits for all local residents that exceed the costs from the society point of view, but are not themselves motivating to visit community gardens.

- The positive results of our cost-benefit analysis of community gardens can be used for economic argumentation when deciding on utilization of undeveloped areas, brownfields or neglected areas.

\section{Keywords}

Community garden, Cost benefit analysis, Ecosystem services, Spatial planning,

Czechia

Received: 12 March 2019

Received in revised form: 29 May 2019

Accepted:

07 June 2019

\section{Introduction}

Impact of globalization on cities, urbanization and, last but not least, ongoing climate change have caused an increasing interest in the quality of life in cities in recent years and possibilities of its improvement. While the global urbanization rate was
$30 \%$ in 1950 , the number rose to $54 \%$ in 2014 . The urbanization rate in Europe was even higher (73\%) and further growth is expected (United Nations 2014). The cities are becoming more vulnerable because of these trends and the need for their adaptation to climate change and higher climate resilience increases. Adaptation strategies (e.g., EU Adaptation Strategy) are being developed and ap- 
propriate measures are implemented in cities in the context of climate change. Negative impacts of climate change significantly reduce the quality of life in cities (e.g., urban heat islands, pollution in cities, storms and floods, etc.) and may ultimately lead to significant impacts on human health and economy (reduced labour productivity, increased health impacts, etc.).

These issues can be partly solved by community gardens (CG). Besides their primary function (crop growing), CGs have a number of co-benefits for their members (such as meeting people and active leisure activities) and also for the whole society. Depending on their specific form and location, CGs regulate microclimate of the district, regulate water runoff and provide other ecosystem services. CGs can thus be seen as one of the adaptation measures or nature based solutions for urban adaptation to climate change that should increase quality of life in the cities. Are members of community gardens affected by any of those social benefits? Are they motivated by those social benefits to visit CG?

The aim of this paper is a comparison of the benefits perceived by community garden members and the evaluated net social benefits of community gardens in cities for all local residents. The objective of this paper is to find answers to the following two specific questions: Q1) What are the benefits of community gardens perceived by community garden members? Q2) What is the value of the net social benefits of community gardens in cities?

The results are presented by using two case studies from CG Kuchyňka and CG Vidimova in Prague, Czechia. A questionnaire survey among members of these two CGs is used to determine perceived benefits by community garden members. A modified cost benefit analysis (CBA) was used to assess the net social benefits of CG. Social benefits represent total benefits for the whole society; they involve both private and external benefits, and both socio economic and environmental effects are in cluded. The concept of ecosystem services was used for the evaluation. This concept makes it possible to identify benefits provided by this type of greenery. Both CGs are continuing to be developed. This economic analysis is based on the costs, benefits and development level from the 2016 season and does not include any projection of future development.

The following chapter deals with the significance of CGs, its benefits and limitations. The third chapter presents methods of the questionnaire survey, the modified cost-benefit analysis and ecosystem services concept and presents the case study areas of CG Kuchyňka and CG Vidimova. The results of the questionnaire survey and economical assessment in the form of costs and benefits are the subject of the fourth chapter, which is followed by discussion and conclusions.

\section{Community gardening, its benefits and limitations}

A community garden (CG) is a type of urban agriculture whose primary function is crop growing and production of food, especially vegetables, fruits and various herbs. According to the international network RUAF Foundation, urban agriculture can be defined in short as "the growing of plants and the raising of animals within and around cities" (de Zeeuw 2004:2), while the more detailed definition emphasizes the difference from rural agriculture and defines urban agriculture as "agriculture embedded in - and interacting with - the urban ecosystem. Such linkages include the use of urban residents as labourers, use of typical urban resources (like organic waste as compost and urban wastewater for irrigation), direct links with urban consumers, direct impacts on urban ecology (positive and negative), being part of the urban food system, competing for land with other urban functions, being influenced by urban policies and plans, etc." (de Zeeuw 2004:2).

Okvat \& Zautra (2011:374) define community gardens as "plots of land used for growing food by people from different families, typically urban dwellers with limited access to their own land". The most frequently reported impacts of community gardens can be divided into the benefits for community members (private benefits) and benefits for the citizens/whole city (external benefits). External benefits contain the following categories: economic benefits, health benefits, ecological benefits, education and others. These two types (private and external benefits) together form the social benefits.

Community gardens are usually established thanks to efforts of likeminded or neighbouring people in an urban area, who pursue their own interests and adapt the community gardens to fulfil local needs (Fox-Kämper 2018). Originally, community gardens were created to grow fresh crops and to fight poverty (Barthel et al. 2013). On the contrary, German research shows that their main objective was to provide an area for recreation, especially for children (Cabral et al. 2017). Nowadays, their importance is not only in benefits for community members and provision of local food (Trendov 2018), but also in promoting urban biodiversity and reducing impacts of climate change. 
Duží et al. (2014) identify three main dimensions associated with urban agriculture. The first of them is that urban agriculture is a type of greenery or green infrastructure. From this perspective, urban agriculture provides several types of benefits for city residents in the form of ecosystem services. Examples of such benefits are habitat for fauna and flora, a place for recreation or sports for visitors, culture services such as meeting points for locals and, last but not least, food production (e.g., Matos \& Batista 2013; Csete \& Horváth 2012; Barthel et al. 2013).

The second dimension is associated with changing lifestyles and spending of leisure time in general. Urban agriculture allows residents to focus more on quality of life and food they consume. It is possible to identify trends in people's behaviour and shifting values towards more responsibility and activity in shopping and consuming (e.g., Kiesling \& Manning 2010; Smith \& Jehlička 2013). The third dimension closely related to urban agriculture is the possibility of achieving at least partial food self-sufficiency and possibly increasing the food security of the region.

Twiss et al. (2003) and Zick et al. (2013) reported similar findings about impacts of community gardening on both an increase in physical activity and fruit and vegetable consumption by members. They also mention improvements in knowledge or skill enhancement, which are part of education ecosystem services.

Other benefits include improved individual wellbeing, such as cognitive benefits, stress relief or less negativity (e.g., Okvat \& Zautra 2011), benefits for the community such as community building and resilience and social interaction or crime prevention (e.g., Guitart et al. 2012; Draper \& Freedman 2010). CGs can also increase property value in the neighbourhood (Voicu \& Been 2008). Using a hedonic regression model and data for New York City, they found a statistically significant positive impact of community garden proximity on property value. The value of adjacent buildings increases by up to $9.4 \%$ five years after the opening of a community garden (Voicu \& Been 2008).

However, there are other effects of urban agriculture and community gardens that may have negative impact on the well-being of city residents. According to Vávra et al. (2018), the total positive or negative effect depends on the type of garden management. Aspects of garden management may negatively outweigh other positive environmental effects by use of mechanized tools, overuse of synthetic fertilisers and pesticides or immoderate water consumption (e.g., Cameron et al. 2012).
Vávra et al. (2018) examined the potential of food self-provisioning to reduce greenhouse gas emissions in a case of 775 Czech households. They found that the share of home-grown fruit and vegetables in the overall consumption led to a reduction of 42-92 kg CO 2 eq/person/year compared to conventional growing. In addition, according to these findings, the positive effects are not negatively balanced by use of fertilisers or by car travel to get to their gardens. This study failed to show that management has negative effects on well-being in Czech conditions.

In contrast, Dewaelheyns et al. (2013) found that garden soils in the northern part of Belgium have a higher acidity, a higher amount of phosphorus and a lower carbon content than optimal agronomic standards.

Säumel et al. (2012) focused on health risks of urban production associated with exposition to pollutants in busy traffic areas. They determined the concentration of trace metal in the crop biomass in urban soil beds and in pots. Their study indicated negative impact of traffic-based air pollution on a higher metal content in the crops and, on the contrary, that the presence of barriers such as buildings or large stands of vegetation significantly reduces trace metal volumes.

Finally, Tregear (2011) examined problems of literature on socio-economic impacts of community gardens and other alternative food networks and presented three main difficulties of research in this field. In relation to CGs, he identified lack of a consumer perspective in assessments of the socioeconomic value of urban agriculture activities.

Urban agriculture (e.g., community gardens or allotment gardening) has generally apparent positive impacts on quality of life of urban populations. Considering the population growth, climate change and other factors mentioned above, its significance can be expected to continue to rise (Čepić et Tomićević-Dubljević, 2017). Despite this, the political environment is not favourable in Central and Eastern Europe. Political and legislative support is insufficient for the urban agriculture development (Duží et al., 2014).

\section{Data and methods}

Two methods were used in this paper in order to compare the benefits perceived by community garden members and the evaluated net social benefits of community gardens in cities for all local residents. A questionnaire survey among members of two community gardens in Prague (CG Vidi- 
Table 1 Economic assessment process based on CBA

\begin{tabular}{lcc}
\hline 1. Project identification and specification & \\
\hline \multirow{2}{*}{ 2. Identification } & \multicolumn{1}{c}{ COSTS } & BENEFITS \\
\cline { 2 - 3 } 3. Qualitative analysis & $\begin{array}{l}\text { According to cost categories } \\
\text { (investment, operating, etc.) }\end{array}$ & $\begin{array}{l}\text { According to the ecosystem } \\
\text { services concept }\end{array}$ \\
\hline 4. Monetization & $\begin{array}{l}\text { Localization of effects, } \\
\text { determination of lifetime }\end{array}$ & $\begin{array}{l}\text { Localization of effects, } \\
\text { time distribution of (co-)benefits }\end{array}$ \\
\hline 5. Net present value & Application of appropriate valuation methods (see Table 3) \\
\hline & Net present value (NPV) for a given time horizon \\
6. Results & $\begin{array}{r}\text { a) Comparison of costs and benefits, profitability determination } \\
\text { b) Inclusion of non-monetized costs and benefits } \\
\text { c) Sensitivity analysis }\end{array}$ \\
\hline
\end{tabular}

mova and CG Kuchyňka) was used to answer the research question of the benefits of community gardens perceived by community garden members. A modified cost-benefit analysis (CBA) was used to assess the social benefits of the community gardens and answer the research question of the value of the net social benefits of community gardens in cities. The concept of ecosystem services was used for the evaluation.

\subsection{Questionnaire survey}

A questionnaire survey was carried out starting in March 2018. On-line questionnaires were sent to contact persons in the community gardens and then transferred directly to their members. Thirteen out of the 23 members of CG Kuchyňka completed the survey, while 24 out of the current 45 members completed the questionnaire in CG Vidimova. That resulted in a return rate of $54.4 \%$. This relatively high return rate can be explained by addressing the members directly through the contact persons and community garden representatives. Another reason is a high interest in development of the community.

The questionnaire contained a total of 30 questions and was divided into 7 sections focusing primarily on perceived benefits of CGs for their surroundings (external benefits) and individuals' motivations to visit CGs and growing their own produce (private benefits). This classification of social benefits is described in Chapter 2 above. Other sections focused on previous experience in growing plants, garden uses, lifestyle, proposals for improvements and questions concerning the demographic indicators and details about the community garden.

The two main sections of the questionnaire contained closed-ended questions concerning the motivations for using CG and perceived benefits for CG surroundings. Possible answers to the closed- ended questions on motivation and perceived benefits were based on current research (e.g., Trendov 2018; Duží et al. 2014; Smith \& Jehlička 2013) and reflected cultural, social or health and other benefits. Other possible answers (both positive and negative effects of CG) could also be suggested by members in open-ended questions.

The purpose of the two main sections of the questionnaire was to determine not only benefits obtained by members (private benefits) but also perceived benefits that CGs have on their surroundings (external benefits). People's motivation for visiting gardens is seen as obtained and main perceived benefits and represents the private benefits. However, members may realize other benefits which need not motivate people to visit CGs. Both obtained and perceived external benefits of CGs for CG surroundings form two parts of benefits of CG perceived by their members as a whole.

\subsection{Modified cost-benefit analysis}

A modified cost-benefit analysis (CBA) was used for the economic evaluation and to determine the net present value (NPV) of a community garden. Unlike financial analysis, CBA also includes external costs and benefits and not only the private costs and benefits (for investors or in this case, CG members). These often do not have a direct financial impact but have a strong influence on well-being of both community garden members and other local residents.

This analysis is based on the concept of the NPV (the present value of benefits minus the present value of costs). That allows comparison of costs and benefits with a different timeframe. Another tool that deals with a different value of money in time is annualization (e.g., Macháč et al. 2016). CBA consists of several steps, which are illustrated in Table 1 below. During the first phase, it is nec- 
essary to identify all costs and benefits. The advantage of evaluating an existing project is the possibility to use known and real values for costs (investment, operating, administrative and opportunity costs). Both costs and benefits are later expressed in monetary terms. Benefits are expressed using appropriate valuation methods. The next step is a conversion to NPV, when all future costs and benefits are converted to the present value and compared. The result represents the net present value of both private and external benefits. To reduce uncertainty, it is necessary to apply a sensitivity analysis, which tests the effect of input variables on the final results and also discusses inclusion of costs and benefits that could not be monetized. In addition, it is also possible to determine the rate of return for the whole society, which indicates how long it will take for the benefits to outweigh the costs associated with the implementation of a project.

Both gardens are still in a development stage. The assessment is based on the 2016 development level and does not include any projection of future development. The economic evaluation is based on the level of costs and benefits from the 2016 season in the prices of the same year.

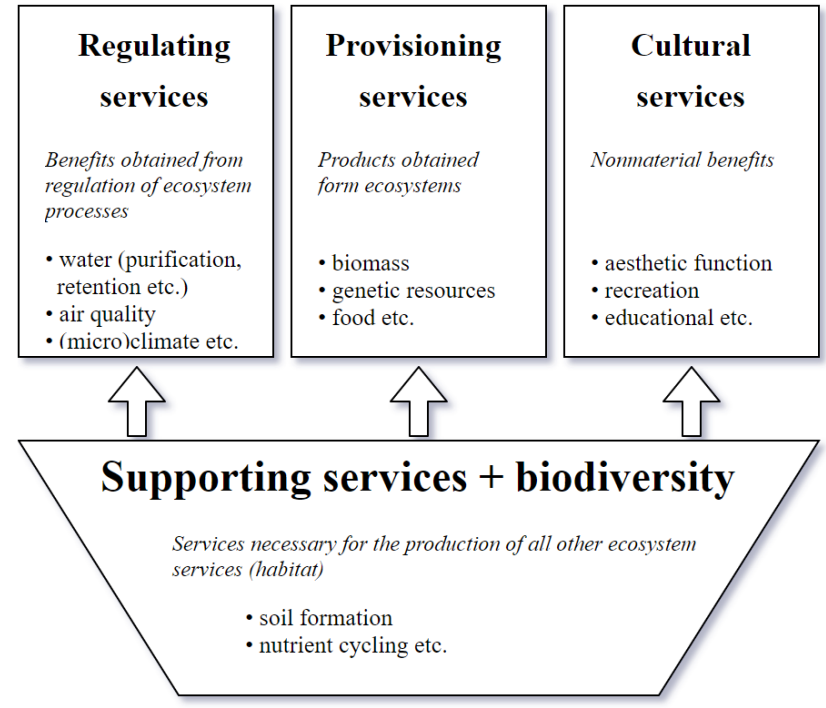

Fig. 1 Categories and types of ecosystem services provided by CG

The benefits are based on the ecosystem services approach and are expressed in monetary terms. The concept of ecosystem services makes it possible to identify benefits provided by greenery. Fisher et al. (2009:645) define ecosystem services as "aspects of ecosystems utilized (actively or passively) to produce human well-being"; alternatively, MEA (2005:40) define them as "the benefits people obtain from ecosystems". Division of ecosystem services into four groups is illustrated in Fig. 1. In the next step, appropriate methods for monetization of identified benefits were chosen (see Table $3)$.

\subsection{Study areas}

A questionnaire survey and a cost-benefit analysis of two different types of community gardens were made. Table 2 shows the main differences and crucial factors of both CG Kuchyňka and CG Vidimova. Over 20 kinds of vegetables were harvested in 2016, along with different types of fruits and herbs. In addition to the crop production, the environment provides recreational and cultural services. Both community gardens are fenced areas. Visitors other than members may enter the gardens during visiting hours. Seminars, workshops and other cultural events such as the opening and closing of the season or Children's Days are held at the community garden Vidimova. The area also provides space for private events, including birthday parties. The operating costs in the case of CG Kuchyňka do not include any special development activities such as kindergarten facilities.

\section{Results}

\subsection{Perceived benefits - results of questionnaire survey}

The objective of the questionnaire survey was to answer research question Q1) What are the benefits of community gardens perceived by community garden members? Perceived benefits consist of both obtained private benefits, which were derived from motivations to visit CG, and perceived external benefits, which stand for benefits that CGs provide for their surroundings and to all local residents, as described above.

At least partial food self-sufficiency was expected as the main motivation for being a community member. Food self sufficiency is also the long term goal of the CG Kuchyňka community. In contrast to the general expectation, the food production is not the most important motivation to be members of both CGs. However, the most important factors for both CG members include the possibility to do leisure activities (especially with their children), the educational function of the garden for children, relaxation and social interaction. Among the less important factors are, for example, well-known origin of the food and its quality. The re- 
sults coincide with the latest findings from abroad (e.g., Cabral et al. 2017).

Based on their answers, community members realize only their private benefits and do not perceive the external benefits. Members fail to realize the impact community gardens have on well-being of the society in the neighbourhood with the exception of biodegradable waste composting and support of local residential interactions. Absorbing rainwater, reducing its runoff, microclimate regulation or air quality controls (e.g., Trendov et al. 2018) are all ignored.

The questionnaire results may be biased by the fact that each questionnaire was filled by only one family member. These are often female. Regarding the socio demographic characteristics of respondents, a typical member of the community garden is a woman, aged 31-40, with at least one child. She has a university degree, attends the garden for 17.7 hours per month on average and lives in a block of flats within walking distance of 500 $\mathrm{m}$ to the community garden (based on modus answers).

Another reason for biased results may be the location of CGs in the city of Prague. Results from smaller cities may differ. Another finding is that the results do not differ significantly for the two community gardens studied.

\subsection{Identified benefits - results of economic assessment (CBA)}

The objective of the economic assessment of CGs based on modified CBA was to answer research question Q2: What is the value of the net social benefits of community gardens in cities?

Table 3 shows both the identified benefits based on the ecosystem service concept and detailed information on how each evaluated benefit was expressed in a monetized form including monetary values (columns "CG K." and "CG V." stand for CG Kuchyňka and CG Vidimova, respectively). This represents steps one to four of the economic assessment process based on CBA presented in Table 1.

In the case of CG Kuchyňka, benefits associated with growing of crops (especially vegetables), rainwater absorption, improving quality of water, air quality regulation, carbon storage and increase in real estate value of surrounding properties (housing estate area) were included in the economic valuation. Other benefits were not expressed in monetary terms. Side activities of the community garden such as the kindergarten were also not included in the analysis.

Development of CG Vidimova has led to increased benefits associated with water retention, capture of harmful substances and carbon storage in the area of new flowerbeds. However, production of crops and biomass, which is used for composting, is the main source of benefits. Additional benefits include recreational and cultural functions con-

Table 2 Comparison of the two case study areas

\begin{tabular}{|c|c|c|}
\hline & CG Kuchyňka & CG Vidimova \\
\hline Year of construction & 2013 & 2013 \\
\hline Location & Prague 8 - Libeň & Prague 11 \\
\hline Size of the area & $3000 \mathrm{~m} 2$ & $1870 \mathrm{~m} 2$ \\
\hline Number of members & 23 (in 2016) & 32 (in 2016) \\
\hline Type of beds & Terraced vegetable beds & Mobile garden beds \\
\hline Ownership of land & Private (Kuchyňka, z.s.) & Public (city district office) \\
\hline Previous land use & $\begin{array}{l}\text { Abandoned area, construction prohibited, } \\
\text { occupied by homeless people }\end{array}$ & Part of a former kindergarten's garden \\
\hline Other information & $\begin{array}{l}\text { Goal: vegetable independence } \\
\text { for } 20-30 \text { families }\end{array}$ & Host of several cultural activities \\
\hline Investment costs & $\begin{array}{c}\text { EUR 18,500* } \\
\text { (include establishment of a civic association, } \\
\text { garden facilities, landscaping, } \\
\text { water inlet, equipment) }\end{array}$ & $\begin{array}{c}\text { EUR 7,400* } \\
\text { (include a shipping container shed and tools, } \\
\text { water and electricity connection, } \\
\text { mobile vegetable beds and composters) }\end{array}$ \\
\hline Operating costs & $\begin{array}{l}\text { EUR 1,110 per year* } \\
\text { (include rent, electricity, plants, } \\
\text { water and sewerage costs, } \\
\text { maintenance costs) }\end{array}$ & $\begin{array}{c}\text { EUR 1,590 per year* } \\
\text { (include rent, electricity, plants, } \\
\text { water and sewerage costs, } \\
\text { costs of garden coordinator, } \\
\text { maintenance costs) }\end{array}$ \\
\hline
\end{tabular}

(c) Jan Evangelista Purkyně University in Ústí nad Labem 
Table 3 Benefits identified, their monetization and methods of valuation

\begin{tabular}{|c|c|c|c|}
\hline \multirow{2}{*}{ Type of benefit } & \multicolumn{2}{|c|}{$\begin{array}{c}\text { Monetary values } \\
\text { (EUR) }\end{array}$} & \multirow{2}{*}{ Valuation methods used } \\
\hline & CG K. & CG V. & \\
\hline $\begin{array}{l}\text { Regulating water } \\
\text { runoff and water } \\
\text { quality improvement } \\
\text { (annual benefit) }\end{array}$ & 800 & 30 & $\begin{array}{l}\text { Avoided cost method combined with market price method: } \\
\text { The benefit was valuated based on additional amount of water retained } \\
\text { on the plots through the gardening, thus the amount of water is not } \\
\text { discharged to the sewage and sewage treatment plant. The total benefit } \\
\text { was calculated as volume of retained water multiply by charges paying } \\
\text { for using sewage treatment system. The usage of land for crop production } \\
\text { led to a higher water retention in comparison to past usage. } \\
\text { The cases differ, because in case of CG Kuchyňka the area has a bigger size. }\end{array}$ \\
\hline $\begin{array}{l}\text { Micro-climate } \\
\text { regulation }\end{array}$ & $\mathrm{X}$ & $\mathrm{X}$ & \\
\hline $\begin{array}{l}\text { Air quality } \\
\text { improvement } \\
\text { (annual benefit) }\end{array}$ & 36 & 4 & $\begin{array}{l}\text { Substitute cost method combined with market price method: } \\
\text { The additional greenery reduces exposure to air pollutants }\left(\mathrm{NO}_{\mathrm{x}}, \mathrm{SO}_{\mathrm{x}}, \mathrm{O}_{3} \text { and } \mathrm{PM}_{\mathrm{x}}\right) \text {. } \\
\text { The amount of pollutants was set based on the type of greenery and its ability } \\
\text { to absorb pollutants) and multiplied by market prices of alternative measures } \\
\text { to reduce the same amount of pollutants. More volume of new greenery was planted } \\
\text { in comparison to past usage in case of CG Kuchyňka. }\end{array}$ \\
\hline Erosion reduction & $\mathrm{X}$ & $\mathrm{X}$ & \\
\hline Noise reduction & $\mathrm{X}$ & $\mathrm{X}$ & \\
\hline $\begin{array}{l}\mathrm{CO}_{2} \text { reduction } \\
\text { (annual benefit) }\end{array}$ & 1 & 0.1 & $\begin{array}{l}\text { Substitute cost method combined with market price method: } \\
\text { The amount of pollutants was set based on the type of greenery and its ability } \\
\text { to absorb } \mathrm{CO}_{2} \text {. The price of } \mathrm{CO}_{2} \text { was set as an average of emission allowance price } \\
\text { and of costs of different substitute measures. The monetary valuation reflects } \\
\text { the volume of new greenery. }\end{array}$ \\
\hline $\begin{array}{l}\text { Biomass } \\
\text { production } \\
\text { (annual benefit) }\end{array}$ & $\mathrm{X}$ & 283 & $\begin{array}{l}\text { Avoided cost method combined with market price method: } \\
\text { Residues from crop production are used together with biodegradable waste produced } \\
\text { in households and leaves and cut grass from the CG to produce compost, which } \\
\text { is necessary for the crop production. CG Vidimova is self-sufficient in compost } \\
\text { production, providing surpluses for other gardens. The valuation is focused } \\
\text { on the surpluses which exceed the self-usage. } \\
\text { Market price method: }\end{array}$ \\
\hline $\begin{array}{l}\text { Crop } \\
\text { production } \\
\text { (annual benefit) }\end{array}$ & 1086 & 200 & $\begin{array}{l}\text { The crops were valuated based on production estimation provided by CGs and market } \\
\text { prices. The valuation was calculated in multiple scenarios (e.g., conventional crops } \\
\text { vs. organic farming), the final level was derived from the average value of different } \\
\text { scenarios. In CG Kuchyňka there is also production of fruit from fruit trees which leads } \\
\text { to higher production and thus higher production benefits. }\end{array}$ \\
\hline Recreational benefits & $\mathrm{X}$ & $\mathrm{X}$ & \\
\hline $\begin{array}{l}\text { Increase in } \\
\text { aesthetic value }\end{array}$ & $\mathrm{X}$ & $\mathrm{X}$ & \\
\hline $\begin{array}{l}\text { Real estate value } \\
\text { (Increase in } \\
\text { aesthetic value) } \\
\text { (one-off increasing) }\end{array}$ & 43770 & 0 & $\begin{array}{l}\text { Market price method: } \\
\text { In the case of CG Kuchyňka, the garden was created in a neglected area, the CG led } \\
\text { to an increase in real estate value in the neighbourhood. In case of CG Vidimova, } \\
\text { the garden was maintained but not to use as CG. The value increase was calculated } \\
\text { based on literature research and current value. }\end{array}$ \\
\hline Habitat creation & $\mathrm{X}$ & $\mathrm{X}$ & \\
\hline Health benefits & $\mathrm{X}$ & $\mathrm{X}$ & \\
\hline $\begin{array}{l}\text { Cultural } \\
\text { and educational } \\
\text { function } \\
\text { (annual benefit) }\end{array}$ & $\mathrm{X}$ & 852 & $\begin{array}{l}\text { Market price method: } \\
\text { The CG Vidimova is often used as a place for workshops or excursions. The value } \\
\text { was estimated based on information about numbers of workshops and excursions } \\
\text { organised in CG Vidimova. }\end{array}$ \\
\hline $\begin{array}{l}\text { Saving of public } \\
\text { expenditure for } \\
\text { greenery maintenance } \\
\text { (annual benefit) }\end{array}$ & $\begin{array}{l}\text { Not } \\
\text { rele- } \\
\text { vant }\end{array}$ & 748 & $\begin{array}{l}\text { Market price method: } \\
\text { The CG Vidimova is located around the municipality office, the garden was } \\
\text { maintained be municipality. In the current time, CG cares about the whole garden. }\end{array}$ \\
\hline
\end{tabular}

* dark background - full provision, light background - limited provision, X - Not monetized 
nected with many events organized in the garden and also excursions for schools or opportunities for leisure activities and spending time with the family. It is possible to include lower costs of greenery maintenance as well, because otherwise the costs would be borne by the city district. Recreational and cultural functions were quantified only in the case of CG Vidimova. Other benefits were not monetized, which underestimates the value of the net social benefits.

The total costs were determined based on the community gardens' construction budgets and operating costs (see Table 2). The comparison of the present value of costs and benefits (step 5 and 6 of CBA process; see Table 1) was done for a 50-year timeframe. For this time horizon, the NPVs for CG Kuchyňka and CG Vidimova were estimated at EUR 31,550 and EUR 1,175 respectively. The values of costs and benefits are illustrated in Table 4.

Table 4 Comparison of costs and benefits

\begin{tabular}{llrr}
\hline & $\begin{array}{l}\text { Present value } \\
\text { of costs } \\
\text { (EUR) }\end{array}$ & $\begin{array}{l}\text { Present value } \\
\text { of benefits } \\
\text { (EUR) }\end{array}$ & $\begin{array}{l}\text { NPV } \\
\text { of benefits } \\
\text { (EUR) }\end{array}$ \\
\cline { 2 - 4 } CG Kuchyňka & 42,640 & 74,190 & 31,550 \\
CG Vidimova & 40,878 & 42,053 & 1,175 \\
\hline
\end{tabular}

The results of the CBA show that both CGs are beneficial for the society and, from a purely economic point of view, supporting and building of these two community gardens makes sense. The monetary value of the benefits does not include all ecosystem services and benefits provided, which underestimates the value of the net social benefits. However, the CBA results show a positive effect on citizen's well-being expressed in terms of ecosystem services. The community gardens' members are willing to maintain the garden with respect to their own motivations (possibility to do leisure activities, educational function for children, relaxation and social interaction) and are thereby causing positive effects for the whole city.

The final value varies depending on the garden's size, location and type of beds (terraced vegetable beds or mobile garden beds), number of members and benefits involved.

The investment will be returned in 3 years for CG Kuchyňka and in 34 years for CG Vidimova from the society point of view. This indicator can be interpreted as a point in time where the measures will start generating benefits for the society beyond the invested costs (investment and operating costs). The results show that the measures may be regarded as an effective measure. The accuracy of the results was verified using a sensitivity analysis based on different levels of discount rates. The interest rate chosen has no effect on the final results and the rate of return for the measures in the case of CG Kuchyňka. For CG Vidimova, however, the investment will be returned after more than 50 years in the case of a pessimistic scenario.

\subsection{Comparison of perceived and identified benefits of CG}

According to the aim of this paper, this section presents the comparison of the benefits perceived by community garden members and the evaluated net social benefits of community gardens in cities for all local residents.

As mentioned above, according to the questionnaire survey, external benefits of community gardens for their surroundings and for all local residents are not perceived by CG members except the establishment of both a public access point for collecting biodegradable waste and of conditions for interactions and relationships within and among households. Members perceive mainly their private benefits in the form of the possibility to do leisure activities (especially with their children), the educational function of the garden for children, relaxation and social interaction and less significant benefits in the form of the well known origin of the food and its quality.

The results of both analyses (questionnaire survey and economic assessment) show that the net social benefits of CG are higher than perceived by CG members. The net social benefits represent both the private benefits and external benefits affecting all local residents. The questionnaire survey indicates that private benefits represent sufficient motivation to visit a CG and become a CG member. However, CGs provide benefits for all local residents that exceed the costs from the society point of view (e.g., increased water retention, higher aesthetic value or contribution to air quality improvement), but are not by themselves motivating to visit community garden.

\section{Discussion}

Differences in results of economic analysis of CGs are related to different local conditions and types of CG. CG Vidimova was established on impervious asphalt roads and approximately 50 elevated mobile garden beds and several composters made of pallets are situated in the garden. In contrast, CG Kuchyňka was established on undeveloped land and is made up of terraced vegetable beds. 
The establishment of CG Kuchyňka led to an increase in aesthetic value, because the territory of a former allotment garden had been neglected. According to the questionnaire survey members of CG Kuchyňka now feel much safer around CG. For the same purpose, the results are difficult to extrapolate because the baseline situation and surrounding conditions nearly always differ.

The general expectation that the most important motivation aspect is own food production was not confirmed by the case studies. More important was doing leisure activities and the social and community aspect. Allotment gardens, an alternative to CGs, are historically popular among residents of Czech cities. The main reason for owning or renting a space in an allotment garden has been crop production. Based on findings related to the motivation of CG members, it makes sense to validate the motivation of users of allotment gardens.

Based on the literature review, the positive effect of urban agriculture and community gardens is very often discussed in the context of $\mathrm{CO}_{2}$ production (Vávra et al. 2018). There are doubts whether the positive effects of greenery to absorb $\mathrm{CO}_{2}$ and other greenhouse gases are not eliminated by $\mathrm{CO}_{2}$ produced by accompanying activities related to urban agriculture such as members' travel to the CG, grass mowing, etc. This negative effect was partly explored in the questionnaire survey. We collected information on the distance between the CG and homes, the way the members get to the CG and whether the CG members have a car for private use. Based on the results, most members walk to the garden or use public transport, and only 2 out of the 37 members use cars; therefore, the negative effect can be omitted in both CGs. Only $60 \%$ of the member families have cars for private use.

It should be noted, however, that the questionnaire survey was made only among current CG members, which might lead to a bias in the context of support, demand for CGs and further results. Excluded were all residents in the neighborhood who are not CG members, who may perceive different or even greater benefits and positive or negative effects of CGs. The questions remain how much they know about the possibilities of becoming a member and if they are interested in doing so.

Monetization of the production function is one of the main challenges. The value is affected by both the amount of production and prices used. However, the majority of members or representatives of CGs do not monitor the amount of production. As stated above in Table 3, the evaluation is based on information from those of the members who are aware of the production as well as estimates provided by other members and the community garden coordinator and partly on estimates derived from a survey on other CGs in the Czech Republic. Alternatively, the CGs may use common production evidence. Such a proxy is not available in the Czech Republic, so that exact follow-up of the quantities and types of food is needed. The question also arises whether use to prices of organic (BIO) or standard quality of fruits, vegetables and herbs. CG production can be deemed to be organic quality. Regarding the anthropocentric point of view, it was necessary to discover whether members buy organic or standard quality food. The question is also whether to use market prices based on prices in retail or prices paid out to producers by dealers/traders/retailers.

\section{Conclusions}

According to the economic analysis, community gardens can be used as economically efficient nature based solutions for urban adaptation to climate change. The results may also be used for economic argumentation when deciding on utilization of undeveloped areas, brownfields or neglected areas in the urban environment. Abandoned industrial sites, cemeteries or ruins represent potential reservoirs of urban biodiversity and with support from urban and spatial planners. Many of these sites can be converted to valuable habitats with positive impacts on human well-being. Such areas can provide higher quality of life in cities.

In the light of current scientific knowledge, the current political and legislative environment limits CG development in Central and Eastern Europe and there is no support leading to sustainable development. It may be caused by lack of recognition of importance of urban gardening, its contribution to climate change adaptation or provision of benefits for all local residents. Solving these issues and incorporating urban agriculture and community gardening into policy-making is a challenge for current and future urban and spatial planners at the regional and local levels.

This economic analysis contributes to greater support for community gardens by city governments and spatial planners. Community gardens not only play a significant role for social interaction and relaxation, but can also contribute directly and indirectly to external benefits (benefits for the whole society). In the case of at least partial food selfsufficiency, it is necessary to include in the analysis lower expenditures on fossil fuels for food transport. 
However, the results are in line with findings of other authors dealing with the meaning and importance of urban gardening and urban agriculture. CGs contribute to city adaptation to climate change and provide a wide range of benefits in the form of ecosystem services for their members and other city residents.

An indirect conclusion of this analysis is that it is appropriate to promote community gardening as this measure contributes to city adaptation to climate change and does not require direct financial expenditures from the city budget, but for instance provision of administrative support, subsidies for investment or land from the local government. Membership fees are usually sufficient to run the garden. CG members are motivated to gain private benefits which are connected with the provision of external benefits. Moreover, the results of our comparison of perceived and evaluated benefits shows that the real net social benefits exceed the benefits perceived by community garden members.

\section{Acknowledgement}

We thank the Operational Programme Research, Development and Education of the Czech Republic for financing the project "Smart City - Smart Region - Smart Community" (grant number: CZ.02.1.01/0.0/0.0/17_048/0007435), which has led to the present paper.

\section{References}

Barthel S, Crumney C, Svedin U (2013) Bio-cultural Refugia Safeguarding Diversity of Practices for Food Security and Biodiversity. Global Environmental Change 23(5): 1142-1152.

Barthel S, Parker J, Ernstson H (2013) Food and green space in cities: a resilience lens on gardens and urban environmental movements. Urban Studies 52(7): 1321-1338.

Cabral I, Keim J, Engelmann R, Kraemer R, Siebert J, Bonn A (2017) Ecosystem services of allotment and community gardens: A Leipzig, Germany case study. Urban Forestry \& Urban Greening 23: 44-53.

Cameron RWF, Blanuša T, Taylor JE, Salisbury A, Halstead AJ Henricot B, Thompson K (2012) The domestic garden - Its contribution to urban green infrastructure. Urban Forestry \& Urban Greening 11: 239-137.

Čepić S, Tomićević-Dubljević J (2017) Urban Community and Allotment Gardens: Research Trends and a Look Ahead. Agricultural \& Forestry 63(4): 191-200.

Csete M, Horváth L (2012) Sustainability and Green Development in Urban Policies and Strategies. Applied Ecology and Environmental Research 10(2): 185-194.

Draper C, Freedman D (2010) Review and Analysis of the Benefits, Purposes, and Motivations Associated with Community Gardening in the United States, Journal of Community Practice 18(4): 458-492.
Duží B, Tóth A, Bihuňová M, Stojanov R (2014) Challenges of Urban Agriculture: Highlights on the Czech and Slovak Republic Specific. In: Vávra J, Lapka M, Cudlínová E (eds.) Current Challenges of Central Europe: Society and Environment, Prague, pp. 82-107.

Fisher B, Turner RK, Morling P (2009) Defining and classifying ecosystem services for decision making, Ecological Economics 68(3): 643-653.

Fox-Kämper R (2018) Urban community gardens: An evaluation of governance approaches and related enablers and barriers at different development stages. Landscape and Urban Planning 170: $59-68$

Guitart D, Pickering C, Byrne J (2012) Past results and future directions in urban community gardens research. Urban forestry \& urban greening 11(4): 364-373.

Kiesling F, Manning CM (2010) How Green is Your Thumb? Environmental Gardening Identity and Ecological Gardening Practices. Journal of Environmental Psychology 30: 315-327.

Macháč J, Louda J, Dubová L (2016) Green and blue infrastructure: An opportunity for smart cities?, 2016 Smart Cities Symposium Prague (SCSP), Prague, pp. 1-6.

Matos RS, Batista DS (2013) Urban Agriculture: The Allotment Gardens as Structures of Urban Sustainability. In: Özyavuz M (Ed.), Advances in Landscape Architecture, pp. 457-512.

Millennium Ecosystem Assessment (2005) Ecosystems and Human Well-being: Synthesis, Island Press, Washington, DC.

Okvat HA, Zautra AJ (2011) Community gardening: A parsimonious path to individual, community, and environmental resilience.

American journal of community psychology 47(3-4): 374-387.

Säumel I, Kotsyuk I, Hölscher M, Lenkereit C, Weber F, Kowarik I (2012) How healthy is urban horticulture in high traffic areas? Trace metal concentrations in vegetable crops from plantings within inner city neighbourhoods in Berlin, Germany. Environmental Pollution 165: 124-132.

Slavíková L, Vojáček O, Macháč J, Hekrle M, Ansorge L (2015) Metodika $\mathrm{k}$ aplikaci výjimek $\mathrm{z}$ důvodu nákladové nepřiměřenosti opatření k dosahování dobrého stavu vodních útvarů. Výzkumný ústav vodohospodářský T. G. Masaryka, v.v.i., Praha.

Smith J, Jehlička P (2013) Quiet Sustainability: Fertile Lessons from Europe's Productive Gardeners. Journal of Rural Studies 32: 148-157.

Tregear A (2011) Progressing knowledge in alternative and local food networks: Critical reflections and a research agenda. 27: 419-430

Trendov NM (2018) Comparative study on the motivations that drive urban community gardens in central Eastern Europe, Annals of Agrarian Sciences 16(1): 85-89.

Twiss J, Dickinson J, Duma S, Kleinman T, Paulsen H, Rilveria L (2003) Community gardens: lessons learned from California healthy cities and communities. American journal of public health 93(9): 1435-1439.

United Nations (2014). World Urbanization Prospects: The 2014 Revision, Highlights (ST/ESA/SER.A/352), Department of Economic and Social Affairs, Population Division.

Voicu I, Been V (2008) The Effect of Community Gardens on Neighboring Property Values. Real Estate Economics 36(2): 241-283.

Vávra J, Daňek P, Jehlička P (2018) What is the contribution of food self-provisioning towards environmental sustainability? A case study of active gardeners. Journal of Cleaner Production 185: 1015-1023. 


\section{S sciendo}

De Zeeuw H (2004) The development of Urban Agriculture; some lessons learnt. International Conference"Urban Agriculture, Agro-tourism and City Region Development", Beijing, 10-14 October, 2004.
Zick CD, Smith KR, Kowaleski-Jones L, Uno C, Merrill BJ (2013) Harvesting More Than Vegetables: The Potential Weight Control Benefits of Community Gardening. American Journal of Public Health 103(6): 1110-1115. 